\title{
PENGUJIAN KUALITAS ASPEK MIKROBIOLOGI AIR MINUM ISI ULANG
}

\author{
Indah Puspitasari ${ }^{1, *}$, Niken Indriyati ${ }^{1}$, Victoria Yulita F. ${ }^{1}$, Rolan Rusli ${ }^{1,2, \dagger}$ \\ ${ }^{1}$ Laboratorium Penelitian dan Pengembangan Kefarmasian "Farmaka Tropis", \\ Fakultas Farmasi, Universitas Mulawarman, Samarinda \\ *Email : puspita94.ip@gmail.com \\ ${ }^{2}$ Kelompok Bidang Ilmu Kimia Farmasi, Fakultas Farmasi, \\ Universitas Mulawarman, Samarinda \\ †Email: rolan@farmasi.unmul.ac.id
}

\begin{abstract}
Recently, refilled drinking water stores are flourishing in the some cities of Indonesia, especially Samarinda. Every refilled drinking water stores are obliged to do inspection of product quality prescribed by the regulations. This research tries to find out the quality testing of microbiological aspects of refilled drinking water were taken from three shops around Pramuka street in Samarinda. The microbiological test of refilled drinking water was to detect the availability of Coliform bacteria with total plate count (TPC) method, microbiological test with most probable number (MPN) method, and identification of some Coliform and pathogen bacterial such as Escherichia coli, Salmonella thyposa, and Staphylococcus aureus. The result showed that none of the samples of refilled drinking water had the total number of bacteria above of the limit number according to the standard about the quality and requirement of drinking water as well as the samples tested did not contain Escherichia coli and Salmonella thyposa, but two samples contained Staphylococcus aureus.
\end{abstract}

Key word : refilled drinking water, microbiological test, coliform and pathogen bacteria, Most Probable Number (MPN), total plate count (TPC)

\begin{abstract}
ABSTRAK
Beberapa tahun terakhir ini usaha air minum isi ulang telah berkembang pesat di di Indonesia, khususnya di Kota Samarinda. Setiap usaha air minum wajib melakukan pemeriksaan mutu produk sesuai dengan peraturan yang berlaku. Penelitian ini dilakukan untuk memperoleh gambaran kualitas aspek mikrobiologi air minum isi ulang yang dijual di tiga depo air minum isi ulang di Samarinda. Pengujian mikrobiologis dilakukan meliputi pemeriksaan angka cemaran bakteri dengan
\end{abstract}


metode angka lempeng total (ALT), pemeriksaan mikrobiologis dengan Most Probable Number (MPN), serta pemeriksaan bakteri koliform dan bakteri patogen, seperti Escherichia coli, Salmonella thyposa, dan Staphylococcus aureus. Hasil penelitian menunjukkan bahwa tidak ada satupun sampel yang melebihi batas yang dipersyaratkan dalam air minum serta sampel yang diuji tidak mengandung Escherichia coli dan Salmonella thyposa, namun 2 sampel mengandung bakteri Staphylococcus aureus.

Kata kunci: air minum isi ulang, pemeriksaan mikrobiologi, bakteri koliform dan patogen, Most Probable Number (MPN), angka lempeng total (ALT)

\section{PENDAHULUAN}

Air yang baik dan aman untuk diminum adalah air yang bebas dari mikroorganisme penyebab penyakit dan zat kimia yang merusak kesehatan, sehingga pengadaan air bersih untuk keperluan air minum harus memenuhi persyaratan yang sudah ditetapkan oleh pemerintah [1]. Standar mutu air minum atau air untuk kebutuhan rumah tangga ditetapkan berdasarkan peraturan Menteri Kesehatan Republik Indonesia No.492/MENKES/PER/IV/2010 tentang persyaratan kualitas air minum [2].

Salah satu upaya atau cara untuk memenuhi kebutuhan air minum adalah dengan adanya produksi air minum isi ulang yang pada saat ini telah berkembang dengan pesat. Sumber air yang diolah dari depo-depo air minum tersebut berasal dari Perusahaan Daerah Air Minum (PDAM) yang terdapat di setiap Kabupaten atau Kotamadya di seluruh Indonesia. Untuk kota Samarinda, air baku yang diolah oleh PDAM Samarinda berasal dari Sungai Mahakam. Air Sungai Mahakam ini memiliki kualitas yang sangat buruk.

Menurut Peraturan Daerah Provinsi Kalimantan Timur Nomor 02 Tahun 2011 tentang pengelolaan kualitas air dan pengendalian pencemaran air, untuk mengetahui perubahan kualitas air pada sumber air dilakukan pemantauan kualitas air paling sedikit 2 (dua) kali dalam 1 (satu) tahun [3] dan dibandingkan dengan ALT (angka lempeng total) yang ditetapkan oleh pemerintah. Walaupun setiap depo air minum diharuskan memiliki sertifikat analisa air dari Laboratorium Kesehatan, namun tidak semua produsen air minum di Samarinda patuh dalam melakukan pemeriksaan berkala untuk mengetahui kualitas dari air minum isi ulang yang diproduksinya. Oleh karena itu, untuk mengetahui kualitas air minum yang diproduksi oleh produsen air minum isi ulang berdasarkan aspek mikrobiologinya berdasarkan peraturan pemerintah, perlu dilakukan pengujian terhadap kualitas air minum di tiga depo air minum isi ulang di kota Samarinda. 


\section{METODE PENELITIAN}

\section{Bahan}

Bahan-bahan yang digunakan dalam penelitian ini antara lain sampel air minum isi ulang, medium NA (MERCK), Medium LB (MERCK), indikator methylen blue, medium EMBA (MERCK), medium SSA (MERCK), dan medium MSA (MERCK).

\section{Peralatan}

Peralatan yang digunakan dalam penelitian ini antara lain timbangan analitik, lemari pendingin, tabung reaksi, tabung durham, cawan petri, botol pengencer, Erlenmeyer, hot plate, spoid, pembakar spiritus, batang pengaduk, serta ose bulat.

\section{Prosedur Penelitian}

\section{Pengambilan Sampel}

Sampel diperoleh dari 3 depo air minum isi ulang di Samarinda, Kalimantan Timur. Sampel tersebut dipindahkan ke dalam wadah dari stainless baru dan bersih yang telah disterilkan sebelumnya agar terhindar dari kontaminan yang tidak diinginkan dan untuk mempermudah proses pengambilan sampel. Selanjutnya sampel dibawa ke Laboratorium Penelitian dan pengembangan FARMAKA TROPIS Fakultas Farmasi Universitas Mulawarman Samarinda untuk kemudian dilakukan penelitian.

\section{Penentuan Kualitas Air Minum Isi Ulang}

Penentuan kualitas air minum dilakukan dengan menggunakan metode angka lempeng total (ALT). Medium yang digunakan pada metode ini adalah medium NA yang merupakan medium umum untuk menumbuhkan bakteri. Sampel yang telah diambil dan disiapkan kemudian dibuat pengenceran bertingkat, khusus untuk bakteri yaitu $10^{-2}, 10^{-3}$, dan $10^{-4}$. Sampel yang telah dilakukan pengenceran tersebut dimasukkan ke dalam cawan petri yang sebelumnya telah dimasukkan medium NA dan ditunggu hingga memadat untuk kemudian diinkubasi pada suhu $37{ }^{\circ} \mathrm{C}$ selama $1 \times 24$ jam untuk menumbuhkan bakteri. Selanjutnya sampel diambil dan diamati koloni-koloninya yang tumbuh lalu dibandingkan dengan standar air minum menurut SNI untuk melihat kualitas air minum yang diuji tersebut.

\section{Pengujian Bakteri Koliform}

Pengujian ini dilakukan menggunakan metode Most Probable Number (MPN) dengan medium LB dan indikator methylen blue untuk melihat ada atau tidaknya bakteri koliform dalam sampel yang akan diuji. Sampel yang telah disiapkan dan sudah mengalami pengenceran bertingkat, yaitu pengenceran $10^{-2}$, $10^{-3}$, dan $10^{-4}$ dimasukkan ke dalam tabung reaksi yang terlebih dahulu dimasukkan tabung durham beserta dengan medium LB dan indikator methylen blue. Sampel kemudian diinkubasi selama $1 \times 24$ jam pada suhu $37{ }^{\circ} \mathrm{C}$ dan diamati keesokan harinya. Adanya gelembung gas dan perubahan medium menjadi kuning pada 
sampel menandakan reaksi positif terdapatnya bakteri koliform dalam sampel air minum.

\section{Identifikasi Bakteri Koliform dan Patogen}

Bakteri koliform maupun patogen dapat diidentifikasi dengan menggunakan medium-medium yang selektif terhadap masing-masing bakteri. Bakteri yang akan diidentifikasi meliputi Escherichia coli, Salmonella thyposa, dan Staphylococcus aureus. Biakan bakteri yang positif dari pengujian sebelumnya ditambahkan medium selektif yaitu EMBA, SSA, dan MSA kemudian diinkubasi selama $1 \times 24$ jam pada suhu $37^{\circ} \mathrm{C}$, diamati dan diperhatikan reaksi positif dari masing-masing medium yang berisi bakteri, dimana untuk medium EMBA reaksi positif adalah timbul warna hijau metalik, SSA warna merah muda, dan MSA menghasilkan koloni kuning dengan zona kuning.

\section{HASIL DAN PEMBAHASAN}

Air minum adalah air yang melalui proses pengolahan atau tanpa proses pengolahan yang memenuhi syarat kesehatan dan dapat langsung diminum [2]. Berdasarkan Standar Nasional Indonesia (SNI) 7388 tahun 2009 tentang batasan maksimum cemaran mikroba dalam pangan, ditetapkan bahwa persyaratan mutu air minum dalam kemasan harus memenuhi batas cemaran mikroba yang terdiri dari penentuan angka lempeng total (ALT), angka bakteri koliform dengan metode MPN, dan identifikasi bakteri patogen [4].

Angka lempeng total (ALT) adalah bilangan yang menyatakan perkiraan jumlah bakteri aerob, yaitu bakteri yang membutuhkan oksigen untuk proses respirasi, pertumbuhan, kelangsungan hidup, dan bereproduksi [5]. Pada uji ALT bakteri, medium yang digunakan adalah medium Nutrient Agar (NA), sebab medium ini mengandung karbon dan nitrogen yang dapat digunakan oleh bakteri untuk melakukan proses metabolisme. Hasil pengujian ini kemudian dibandingkan dengan batasan maksimum cemaran mikroba dalam pangan dalam Standar Nasional Indonesia (SNI) 7388 tahun 2009 [4].

Tabel 1. Hasil Pengujian Angka Lempeng Total (ALT) Sampel Air Minum Isi Ulang yang Menunjukkan kualitas air minum dari aspek mikrobiologi

\begin{tabular}{ccccc}
\hline \multirow{2}{*}{ Sampel Air Minum } & \multicolumn{3}{c}{ Pengenceran } & \multirow{2}{*}{ Pelaporan } \\
\cline { 2 - 4 } & $10^{-2}$ & $10^{-3}$ & $10^{-4}$ & $1 \times 10^{2}$ \\
Sampel 1 & 0 & 0 & 0 & $1 \times 10^{2}$ \\
Sampel 2 & 0 & 0 & 0 & $1,57 \times 10^{4}$ \\
Sampel 3 & 157 & 44 & 27 & \\
\hline
\end{tabular}

Sebagaimana yang terlihat pada Tabel 1, dari ketiga sampel yang diambil dari 3 (tiga) depo air minum isi ulang yang berbeda diketahui bahwa nilai ALT dari sampel 1 dan 2 sebesar $1 \times 10^{2} \mathrm{koloni} / \mathrm{mL}$ dan sampel 3 sebesar $1,57 \times 10^{4} \mathrm{koloni} / \mathrm{mL}$. Hasil ini menunjukkan bahwa dari ketiga sampel tersebut angka lempeng totalnya 
(ALT) masih masuk dalam batas cemaran mikroba yang dipersyaratkan oleh Standar Nasional Indonesia (SNI) 7388 tahun 2009 tentang batasan maksimum cemaran mikroba dalam pangan, yaitu $1,0 \times 10^{5} \mathrm{koloni} / \mathrm{mL}$ [4].

Metode pengujian Most Probable Number (MPN) digunakan untuk mengetahui adanya bakteri koliform dalam makanan maupun minuman, dan metode ini dilakukan untuk menghitung jumlah mikroba di dalam sampel yang berbentuk cair [6]. Pertumbuhan bakteri koliform setelah dicuplikan atau diinokulasikan pada media cair yang sesuai, kemudian diamati adanya perubahan warna dari medium dan terbentuknya gas dalam tabung durham yang diletakkan dengan cara terbalik [5]. Pembacaan hasil uji dilihat dari berapa tabung uji yang menghasilkan gas dan asam ( 3 seri pertama, kedua, dan ketiga), hasil yang positif asam dan gas dibandingkan dengan tabel MPN/JPT (Jumlah Perkiraan Terdekat).

Medium yang digunakan adalah Lactose Broth (LB). Medium ini digunakan bertujuan untuk mengetahui ada tidaknya kehadiran bakteri koliform berdasarkan terbentuknya asam dan gas yang disebabkan karena fermentasi laktosa yang terdapat dari medium tersebut. Medium ini dapat menghambat pertumbuhan bakteri gram positif dan meningkatkan pertumbuhan bakteri koliform. Hasil positif yaitu terjadinya perubahan warna medium LB menjadi kuning keruh dikarenakan kandungan laktosa dalam medium di fermentasi menjadi alkohol dan membentuk asam karboksilat. Asam karboksilat ini yang membuat medium berwarna kuning dan terlihat keruh [7].

Hasil pengujian dengan metode MPN terlihat pada Tabel 2. Ketiga sampel yang diuji positif mengandung bakteri koliform, terlihat dengan adanya tabung yang positif yaitu terjadi perubahan medium menjadi keruh dan terdapat gelembung gas pada tabung durham. Tabung yang positif pada sampel 1 adalah tabung seri pengenceran $10^{-2}$ dan $10^{-3}$, sehingga untuk seri sampel 1 adalah 1-0-1 dengan nilai MPN menurut tabel yakni 7 koloni $/ 100 \mathrm{~mL}$ atau $0,35 \mathrm{koloni} / 5 \mathrm{~mL}$. Sampel 2 hanya positif pada pengenceran $10^{-2}$, sehingga untuk seri sampel 2 adalah 3-0-0 dengan nilai MPN yakni $23 \mathrm{koloni} / 100 \mathrm{~mL}$ atau $1,15 \mathrm{koloni} / 5 \mathrm{~mL}$. Sedangkan pada sampel 3 hasil positif terlihat pada semua seri pengenceran, sehingga untuk sampel 3 adalah 3-1-1 dengan nilai MPN yakni $75 \mathrm{koloni} / 100 \mathrm{~mL}$ atau 3,75 koloni/5 mL. Artinya dari ketiga sampel yang diuji tersebut tidak masuk dalam rentang aman yang dipersyaratkan oleh Standar Nasional Indonesia (SNI) 7388 tahun 2009 yang menyebutkan bahwa syarat-syarat uji cemaran secara mikrobiologi koliform untuk air minum adalah $<2 / 100 \mathrm{~mL}$ [4].

Tabel 2. Hasil Pengujian Most Probable Number (MPN) Sampel Air Minum Isi Ulang yang Menunjukkan keberadaan bakteri koliform

\begin{tabular}{lccccc}
\hline \multirow{2}{*}{ Sampel Air Minum } & \multicolumn{3}{c}{ Pengenceran } & Nilai & Pelaporan Nilai \\
\cline { 2 - 4 } & $10^{-2}$ & $10^{-3}$ & $10^{-4}$ & MPN/100 mL & MPN/5 mL \\
\hline Sampel 1 & +-- & --- & +-- & 7 & 0,35 \\
Sampel 2 & +++ & --- & -- & 23 & 1,15 \\
Sampel 3 & +++ & --+ & -+- & 75 & 3,75 \\
\hline
\end{tabular}


Tabung yang menunjukkan pembentukan gas atau gelembung diuji lebih lanjut dengan menggunakan medium selektif untuk masing-masing bakteri yang akan diidentifikasi, yaitu Escherichia coli, Salmonella thyposa, dan Staphylococcus aureus. Pemeriksaan bakteri Escherichia coli dilakukan dengan menginokulasi sampel yang telah ditanam dalam media uji konfirmasi, pada medium selektif, yaitu Eosin Methylen Blue Agar (EMBA). Medium ini bersifat selektif dalam menumbuhkan Escherichia coli karena dalam medium ini mengandung eosin yang dapat menghambat pertumbuhan bakteri gram positif dan hanya dapat menumbuhkan bakteri gram negatif. Bila biakan terdapat bakteri Escherichia coli maka asam yang dihasilkan dari fermentasi akan menghasilkan warna koloni yang spesifik untuk bakteri Escherichia coli yaitu koloni yang berwarna hijau dengan kilap logam. Adapun mekanisme penampakan warna tersebut adalah adanya eosin dalam medium tersebut berfluoresensi atau memancarkan cahaya sehingga menghasilkan kilap logam atau metalik, dan terjadi reaksi antara methylen blue dan bakteri Escherichia coli yang ada pada medium LB sehingga warna kuning berubah menjadi warna hijau metalik [8].

Hasil identifikasi yang terlihat pada Gambar 1 tidak ditemukan adanya bakteri Escherichia coli, hal ini menunjukkan bahwa dari ketiga sampel yang diperiksa tidak mengandung bakteri Escherichia coli, sehingga tidak dilakukan uji lanjutan.

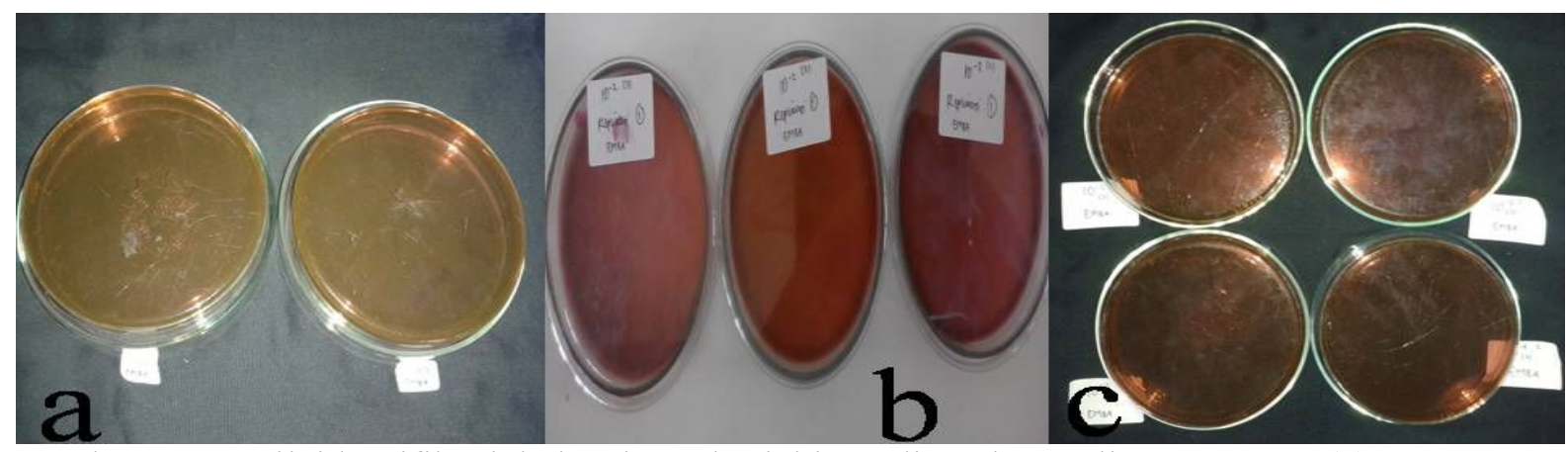

Gambar 1. Hasil identifikasi bakteri Escherichia coli pada medium EMBA (a) sampel 1, (b) sampel 2, dan (c) sampel 3. Hasil identifikasi negatif karena tidak ada koloni dengan kilap hijau metalik.

Uji Salmonella digunakan untuk mengetahui dan menetapkan adanya Salmonella dalam makanan dan minuman. Salmonella merupakan bakteri indikator keamanan pangan, karena Salmonella bersifat patogen sehingga terdapatnya bakteri ini dalam makanan dan air dianggap membahayakan kesehatan. Medium Salmonella-Shigella Agar (SSA) merupakan medium selektif yang dapat mendeteksi Salmonella-Shigella yang tumbuh dan berkembang biak. Medium SSA akan memberikan hasil zona kuning diantara koloni hitam pada medium. Pertumbuhan mikrobanya berwarna merah, dengan atau tanpa pusat yang berwarna hitam. Mikroba melakukan reduksi tiosulfat menjadi sulfat sehingga terlihat sebagai koloni hitam, juga terjadi degradasi laktosa menjadi asam yang 
diindikasikan dengan terbentuknya warna merah. Uji lanjutan yang dilakukan untuk memastikan adanya bakteri Salmonella thyposa, antara lain TSI Agar, urea agar, medium Lysine dekarboxilase, dan pereaksi galaktosidase [8]. Hasil identifikasi yang terlihat pada Gambar 2 tidak ditemukan adanya bakteri Salmonella thyposa, hal ini menunjukkan bahwa dari ketiga sampel yang diperiksa tidak mengandung bakteri Salmonella thyposa, sehingga tidak dilakukan uji lanjutan.

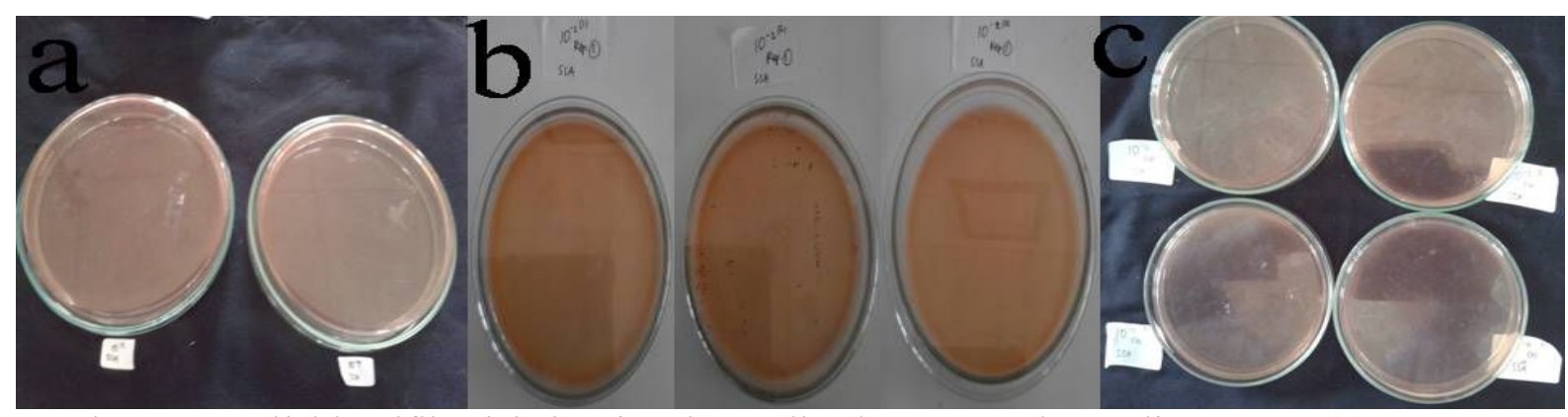

Gambar 2. Hasil identifikasi bakteri Salmonella thyposa pada medium SSA (a) sampel 1, (b) sampel 2, dan (c) sampel 3. Hasil identifikasi negatif karena tidak ada koloni berwarna merah.

Persyaratan batas cemaran bakteri air minum dalam kemasan pada Standar Nasional Indonesia (SNI) 7388 tahun 2009 tentang batasan maksimum cemaran mikroba dalam pangan hanya mencantumkan bahwa bakteri Salmonella, Pseudomonas aeruginosa, dan Escherichia coli yang tidak boleh ada di dalam air minum dalam kemasan dan tidak diharuskan untuk mengidentifikasi keberadaan bakteri Staphylococcus aureus [4]. Namun demikian, pada penelitian ini perlu dilakukan untuk mengidentifikasi keberadaan bakteri Staphylococcus aureus, karena bakteri yang sering ditemukan sebagai flora normal pada kulit dan selaput lendir manusia ini dapat menghasilkan enterotoksin yang seringkali menjadi penyebab keracunan pada makanan dan minuman [9].

Mannitol Salt Agar (MSA) adalah medium selektif diferensial untuk isolasi Staphylococcus patogen, yaitu Staphylococcus aureus. Bakteri tersebut pada medium mannitol salt agar (MSA) akan terlihat sebagai koloni berwarna kuning dikelilingi zona kuning keemasan karena kemampuan memfermentasi mannitol. Jika bakteri tidak mampu memfermentasi mannitol, maka akan tampak zona merah atau ungu. Degradasi manitol oleh bakteri menghasilkan produk asam yang mengubah warna medium dari berwarna merah muda menjadi kuning [10].

Hasil identifikasi yang terlihat pada Gambar 3 tidak ditemukan adanya bakteri Staphylococcus aureus pada sampel 1, namun pada sampel 2 dan 3 terbukti adanya bakteri Staphylococcus aureus yang ditandai dengan terjadinya perubahan warna koloni menjadi kuning. Pada uji Staphylococcus aureus ini tidak diperlukan uji lanjutan dikarenakan medium MSA sudah merupakan medium yang akurat untuk mendeteksi adanya bakteri tersebut. 


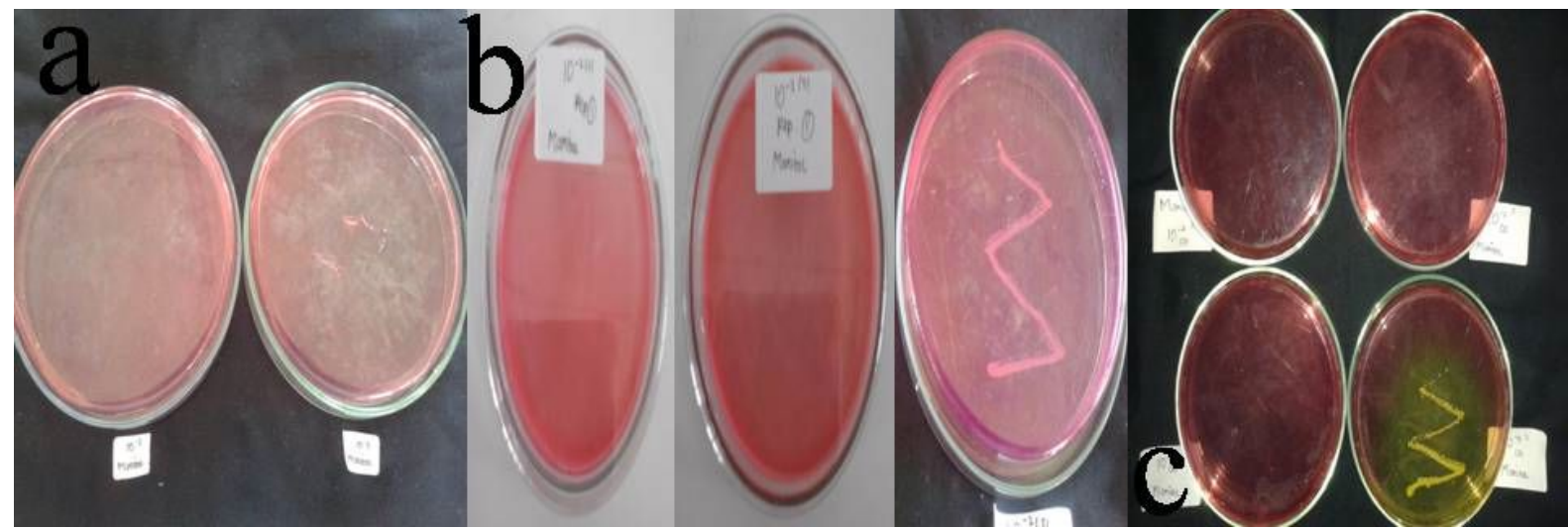

Gambar 3. Hasil identifikasi bakteri Staphylococcus aureus pada medium MSA (a) sampel 1, (b) sampel 2, dan (c) sampel 3. Sampel 1 menunjukkan hasil negatif (tidak terbentuk koloni kuning dengan zona kuning). Sampel 2 dan 3 menunjukkan hasil positif(terbentuk koloni kuning zona kuning).

\section{KESIMPULAN}

Berdasarkan penelitian ini dapat disimpulkan bahwa semua sampel yang diuji angka cemaran mikrobanya dengan metode ALT masuk dalam batas yang telah ditetapkan oleh Standar Nasional Indonesia (SNI) 7388 tahun 2009 tentang batasan maksimum cemaran mikroba dalam pangan, yaitu $1,0 \times 10^{5} \mathrm{koloni} / \mathrm{mL}$ air minum, namun dengan metode MPN tidak ada satupun yang masuk dalam batas yang dipersyaratkan, yaitu $<2 / 100 \mathrm{~mL}$. Semua sampel tersebut tidak mengandung bakteri Escherichia coli dan Salmonella thyposa, namun dua sampel mengandung bakteri Staphylococcus aureus.

\section{DAFTAR PUSTAKA}

[1] Kusnaedi. 2010. Mengolah Air Kotor untuk Air Minum. Penebar Swadaya. Depok.

[2] Peraturan Menteri Kesehatan RI No. 492/MENKES/PER/IV/2010 tentang Persyaratan Kualitas Air Minum. Departemen Kesehatan RI.

[3] Peraturan Daerah Provinsi Kalimantan Timur Nomor 02 Tahun 2011 tentang Pengelolaan Kualitas Air dan Pengendalian Pencemaran Air. Peraturan Daerah Provinsi Kalimantan Timur.

[4] Badan Standardisasi Nasional. 2009. Batas Maksimum Cemaran Mikroba dalam Pangan Standar Nasional Indonesia (SNI) 7388.

[5] Djide, N. dan Sartini. 2008. Analisis Mikrobiologi Farmasi. Laboratorium Mikrobiologi Farmasi Fakultas Farmasi Universitas Hasanuddin. Makassar.

[6] Harmita dan M. Radji. 2008. Buku Ajar Analisis Hayati Edisi 3. EGC. Jakarta. 
[7] Widiyanti, N.L.P.M. dan Ni Putu R. 2004. Analisis Kualitatif Bakteri Koliform pada Depo Air Minum Isi Ulang di Kota Singaraja Bali. Jurnal Ekologi Kesehatan. 3. (1). 64-73.

[8] Aulia, F.N. 2013. Analisis Keberadaan Mikroba pada Air Baku PDAM Kabupaten Situbondo. Universitas Jember: Jember.

[9] Radji, M., Heria O. dan Herman S. 2008. Pemeriksaan Bakteriologis Air Minum Isi Ulang di Beberapa Depo Air Minum Isi Ulang di Daerah Lenteng Agung dan srengseng Sawah Jakarta Selatan. Majalah Ilmu Kefarmasian. 5. (2). 101109.

[10] Dewi, A. K. 2013. Isolasi, Identifikasi dan Uji Sensitivitas Staphylococcus aureus terhadap Amoxicillin dari Sampel Susu Kambing Peranakan Ettawa (PE) Penderita Mastitis di Wilayah Girimulyo, Kulonprogo, Yogyakarta. Jurnal Sain Veteriner. 31. (2). 1-13. 